cialists, who are required by the current law to sign the paper necessary for proceeding to physician-assisted suicide. Nitschke says that Northern Territory doctors who support the new law now believe the only way the law can be made workable is to get a specialist from another part of Australia to register in the Northern Territory and get on its electoral rolls in order to comply with the amended law.

Ironically, even if the law passes all the various challenges, nobody except the coroner will know how it is being used. The Northern Territory does not have a Freedom-of-Information act, and after reviewing the paperwork, the coroner's office is only required to prepare an annual report to Parliament of the actual number of people who took advantage of the law. In other words, an outstanding issue with the new law is the need for public scrutiny to ensure that it is not being abused, the very reason the various medico-legal hurdles blocking Nitschke's efforts to help patients like Max Bell to die have been put into the law in the first place.

ELIZABETH BAN Sydney, Australia

\title{
Has the RAC reached the end of the road?
}

Nearly two years after the idea was first floated, a July 8 notice in the US Federal Register announced that Harold Varmus, director of the US National Institutes of Health, intends to dissolve the $\mathrm{NIH}$ Recombinant DNA Advisory Committee (RAC). In place of the RAC, Varmus is proposing an Office of Recombinant DNA Activities Advisory Committee (OAC), which would not have the authority to stamp approval on individual research protocols. Opinion on the proposed change is strongly divided.

For the past six years the RAC has overseen gene therapy protocols and conducted public reviews and approvals to ensure the safety and well being of human subjects and the community. However, protocols were also subject to approval by the US Food and Drug Administration, leading to calls from the scientific community for streamlining the long approval process. In recent months, under a policy of "consolidated review" adopted by the RAC in conjunction with the FDA, only protocols judged to be "novel" went through the RAC, with all others being forwarded directly to the FDA.

Since May, when Varmus first publically announced his intention to dissolve the RAC entirely, strong opinions have been voiced on the merits of the proposal. Comments received in response to the Federal Register notice revealed that scientists, including past and present members of the RAC, were both for and against the proposed changes; private citizens were also split in opinion; public interest groups and foundations for various diseases were overwhelmingly against the changes; and the biotechnology and pharmaceutical industries were in favor of the changes.

Inder Verma of the Salk Institute in La Jolla, California, who chaired an ad hoc committee last year to review the activities of the RAC, calls the Varmus proposal a "step in the right direction." Arthur Caplan, director of the Center of Bioethics at the University of Pennsylvania, agrees that it is time for reform. Whereas the RAC was needed in earlier days to ensure safety, "gene interventions have not proven to be especially risky," said Caplan.

W. French Anderson, a scientist at the University of Southern California and pioneer in gene therapy, believes that although the FDA can address safety concerns, significant social concerns still remain, and he feels that the credibility and respect that the RAC has with the public makes it ideally suited to address them. "If there weren't political reasons," said Anderson, "it makes no sense (to get rid of the RAC)." Anderson said the proposed OAC is merely "window dressing," and questions whether any well-estab- lished, busy scientist will be willing to sit on it, as it will lack any "real authority."

The OAC would still have access to the same protocols to which the RAC had access, but even if the OAC is successful in capturing and addressing novel protocols, there is skepticism that its "recommendations" will carry as much weight with the FDA as the formal stamp of approval of the RAC. "Without the authority to approve," Therese Lysaught, a RAC member, writes in a letter to Varmus, "there is no guarantee that any recommendations ... will be followed." Lana Skirboll, NIH associate director for science policy, also points out that even with a stamp of approval, NIH has never had the authority to regulate, and that the FDA following the RAC's approval has "only been a gentlemen's agreement for all intents and purposes."

IRIS KEDAR Washington, $D C$

\section{Another federal bioethics commission is born}

On 19 July, President Clinton appointed the first members to the newly formed National Bioethics Advisory Commission (NBAC). Created by executive order last October, the NBAC will advise the National Science and Technology Council and the public on bioethical issues, but will not review or approve specific projects. Initially, the committee is to address issues pertaining to genetic information, including gene patenting, and the protection of the rights and welfare of human research subjects.

The NBAC faces a number of battles, the first of which may be to show the public that it can surmount differences of opinion crumbling (as did a previous bioethics advisory commission). Issues involving the use and management of genetic information, perhaps not as divisive as those pertaining to abortion, will not be easy to tackle. For example, although several states have laws concerning genetic information, with respect to federal laws, "there's nothing out there right now that clearly addresses the unusual nature of genetic information in the insurance context," said Michael Malinowski, an attorney with special expertise in biotechnology, who adds that Europe already has several wellestablished bioethics commissions (just last month, Britain, which already has the highly respected Nuffield Council on Bioethics, announced its plans to set up a Human Genetic Advisory Commission (Nature Medicine 2, 839; 1996)

The commission, to be headed by Harold Shapiro, president of Princeton University, is scheduled to meet for the first time in October. 